\title{
RESPIROMETRIC ACTIVITY OF ACTIVATED SLUDGE AND BIOFILM IN IFAS-MBBR SYSTEM
}

\author{
Paula Piechna', Monika Żubrowska-Sudoł' \\ ${ }^{1}$ Warsaw University of Technology, Faculty of Building Services, Hydro and Environmental Engineering, \\ Department of Water Supply and Wastewater Treatment, Warsaw, Poland, e-mail: piechna.paula@gmail.com
}

Received: 2017.05.05 Accepted: 2017.06.05 Published: 2017.07.01

\begin{abstract}
The aim of the presented study was: a) assessment of activity of microorganisms developed in form of activated sludge and biofilm, b) indirect assessment of the role of analyzed biocoenoses in removal of organic compounds in hybrid reactor with moving bed. Oxygen uptake rate tests (OUR) have been used, and obtained results were presented as volumetric activity $\left(v_{o 2}^{V}\right.$, expressed in $\left.\mathrm{mg} \mathrm{O}_{2} / \mathrm{L} \cdot \mathrm{h}\right)$ and mass activity $\left(v_{o 2}^{m}\right.$, expressed as $\mathrm{mg} \mathrm{O}_{2} / \mathrm{g}$ VTS $\left.\cdot \mathrm{h}\right)$. Tests were conducted for three different variants, in which, as the biomass: 1) biofilm was used, 2) activated sludge was used, 3) biofilm and activated sludge were used. The biomass was collected from aerobic reactor from a wastewater treatment plant working in IFAS-MBBR system. The highest volumetric activity was observed for variant with biofilm and activated sludge, and the lowest for variant with biofilm only. Nonetheless, the highest value of oxygen uptake rate related to total volatile solids was observed for variant with biofilm and the lowest for activated sludge. Obtained results suggest, that during this research, at the wastewater treatment plant, the main role in removal of organic pollutants played the biomass developed in form of activated sludge.
\end{abstract}

Keywords: IFAS-MBBR, activated sludge, biofilm, OUR

\section{INTRODUCTION}

In recent years, a dynamic development of biological methods of wastewater treatment has been observed. At present, the choice of the best technology is not restricted to decision between activated sludge and trickling filters only. New technologies have emerged, such as: membrane systems, moving bed or aerobic granulation. Researchers' attention is drawn also to hybrid systems, which combine the biomass developed in form of activated sludge flocs and biofilm [Jabari et al., 2014; Maider et al., 2015]. When these two biocoenoses are present in one reactor, such systems are called IFAS (Integrated Fixed Film Activated Sludge). An example of such solution is hybrid reactor with moving bed (IFAS-MBBR Moving Bed Biofilm Reactor). In IFAS-MBBR as the biomass carriers free-floating media, with big active surface and density closed to water density, are used [Żubrowska-Sudoł and Jasińska, 2007]. Characteristics of some of the moving bed technologies are to be found in article Podedworna and Żubrowska-Sudot [2011]. The amount of the developed biomass in hybrid reactor is much higher than in reactor working only with activated sludge, because the biomass is present both in form of biofilm and activated sludge. Therefore, there is a possibility to introduce much higher organic pollutants load to the same volume of reactor, and the required volume of IFAS-MBBR are much lower than required volumes of activated sludge reactors [Żubrowska-Sudoł, 2012]. Another technological benefit is providing good environment for growth of nitrifying bacteria regardless solids retention time and hydraulic retention time (this group of bacteria can inhabit biofilm) [Onnis-Hayden et al., 2011].

Two coexisting biomasses in IFAS systems biofilm and activated sludge - can play different 
roles in pollutants removal. Groups of microorganisms inhabiting these biocoenoses can differ [Kim et al., 2011], as well as the physicochemical properties of the surface of activated sludge flocs and biofilm or the physiological functions of these biomasses [Zhang et al., 2015; Huang et al., 2016]. As already mentioned, biomass immobilized on carriers can be characterized by higher solids retention time, on the other hand, the suspended biomass has higher substrate uptake and growth rates [Huang et al., 2016]. Leyva-Díaz et al. [2015] underlined, that coexistence of two biomasses - immobilized and suspended could lead to changes in kinetic parameters of these biocoenoses in comparison with activated sludge technology.

At present, there are in Poland over a dozen municipal wastewater treatment plants (WWTP), which use IFAS-MBBR technology. One of them, designed to biologically remove carbon compounds, nitrogen and phosphorus, is located in Pajęczno (Łódzkie voivodeship). Presented research was conducted for activated sludge and biofilm, developed on moving carriers, collected from mentioned wastewater treatment plant. The conducted experiment, aimed to assess the activity of microorganisms developed in attached and suspended form, and indirectly to assess what was the role of the analyzed biocoenoses in organic compounds removal. Oxygen uptake rate tests (OUR) that were used are a simple tool for tracking the activity of microorganisms responsible for removal of organic pollutants from wastewater [Surmacz-Górska et al., 1996].

\section{MATERIALS AND METHODS}

\section{Materials}

The experiment covered two series (series I and II) conducted in the interval of two months. Samples of activated sludge and carries were collected from aerobic reactor. At the wastewater treatment plant, moving bed type Ev-U Pearl (figure 1) of active surface $800 \mathrm{~m}^{2} / \mathrm{m}^{3}$ has been used as the biofilm carriers. The wastewater treatment plant was designed for mixed liquor suspended solids concentration of $4.0 \mathrm{~kg} / \mathrm{m}^{3}$ and carrier filling ratio of $13 \%$ (during the start-up of the plant, lower amount of moving bed was introduced to the aerobic reactor and the filling ratio was $10 \%$ ). Data according to the wastewater treatment plant was presented in Table 1 .

\section{Oxygen uptake rate tests}

Oxygen uptake rate test (OUR) were conducted in a $300 \mathrm{ml}$ test reactor equipped in optical oxygen sensor FDO*925, which was working with a multiparameter multichannel transducer WTW Multi 3410. Scheme of the research stand was presented in figure 2. OUR tests were conducted for three variants, in which as the biomass: 1) biofilm was used, with the assumption that reactor carrier filling ratio was $10 \%$ (reflection of conditions at wastewater treatment plant) (V1), 2) activated sludge of concentration $2.5 \mathrm{~g}$ TS/L was used (the sludge concentration in tests was lower than the real sludge concentration in the aerobic reactor; in a test, conducted for the sludge concentration at the level of $6.0-8.0 \mathrm{~g} \mathrm{TS} / \mathrm{L}$ (Table 1), the oxygen would be taken up too fast and there would be no possibility to determine the function of this parameter changes in time) (V2), 3) biofilm and activated sludge were used in the amounts given in points 1 and 2 (V3). In each of the experiments, the initial COD value in the test reactor was 150 $\mathrm{mg} \mathrm{O}_{2} / \mathrm{L}$, which was obtained by introduction of acetic acid solution. During the entire test, reactors' content was mixed on magnetic stirrer in order to ensure proper access to substrates to all of the microorganisms in the sample. The oxygen measurement was conducted with 5-step interval.

OUR tests were conducted in 3 repetitions for each variant. The amount of used oxygen was related to the active volume of the test reactor and to the amount of biomass in the reactor. The obtained values were named volumetric activity $\left(v_{o 2}^{V}\right.$, expressed in $\left.\mathrm{mg} \mathrm{O}_{2} / \mathrm{L} \cdot \mathrm{h}\right)$ and mass activity $\left(v_{o 2}^{m}\right.$, expressed as $\mathrm{mg} \mathrm{O}_{2} / \mathrm{g}$ TVS $\left.\cdot \mathrm{h}\right)$, respectively.

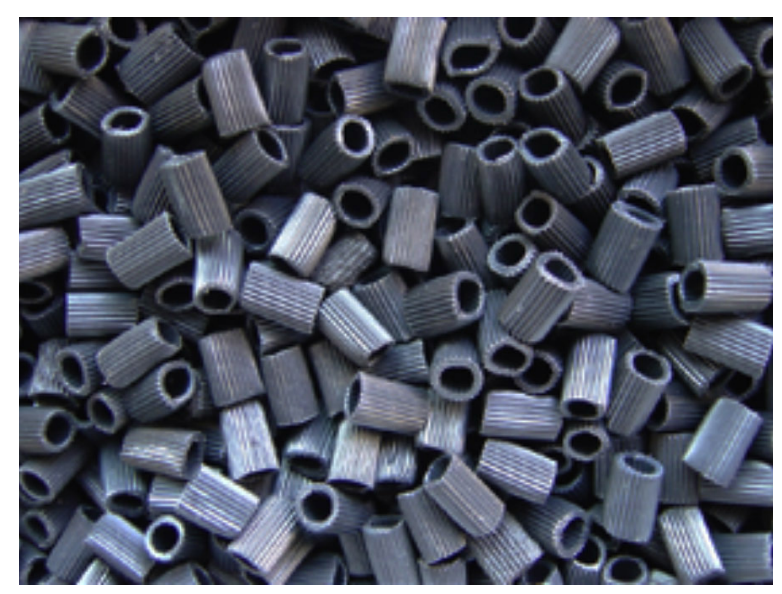

Figure 1. Moving bed type Ev-U Pearl 
Table 1. Design and real values characterizing the wastewater treatment plant in Pajęczno

\begin{tabular}{|l|c|c|}
\hline \multicolumn{1}{|c|}{ Specification } & Design values & Real values - data from 2016 r. \\
\hline PE & 11267 & $11-12$ thous., depending on the season \\
\hline Average day flow & $1200 \mathrm{~m}^{3} / \mathrm{d}$ & $1417 \mathrm{~m}^{3} / \mathrm{d}$ \\
\hline Carrier filling ratio in aerobic reactor & $13 \%$ & $10 \%$ \\
\hline Mixed liquor suspended solids in aerobic reactor & $4.0 \mathrm{~kg} / \mathrm{m}^{3}$ & $6.0-8.0 \mathrm{~kg} / \mathrm{m}^{3}$ \\
\hline Solids retention time & $20-25 \mathrm{~d}$ & $10-15 \mathrm{~d}$ \\
\hline Volumetric loading & $0.38 \mathrm{~kg} \mathrm{BOD} /\left(\mathrm{m}^{3} \cdot \mathrm{d}\right)$ & $0.47 \mathrm{~kg} \mathrm{BOD}$ \\
\hline
\end{tabular}
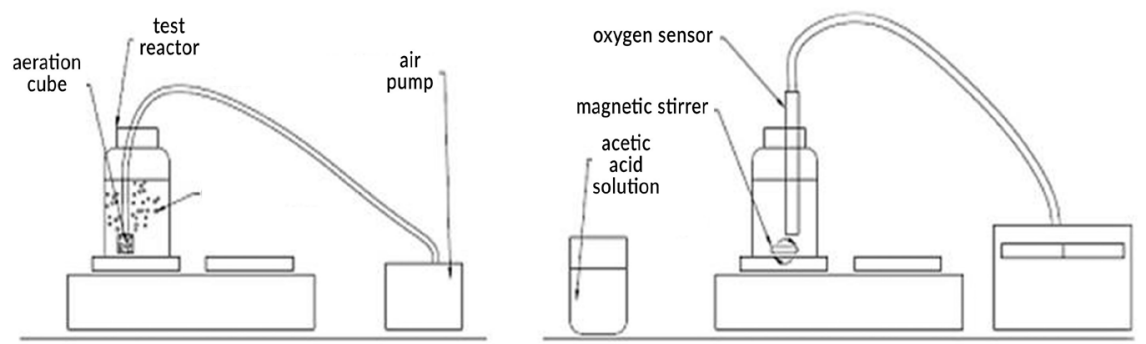

Figure 2. Scheme of the research stand for conducting the OUR tests.

\section{Analytics}

Concentration of activated sludge was calculated based on weighing method according to norm PN-EN 12879:2004. The total volatile solids in biofilm growing on carriers was calculated also based on weighing method, by burning the sample in $550^{\circ} \mathrm{C}$. The biofilm was mechanically removed from the carriers and than it was washed in $0.28 \%$ solution of sodium pyrophosphate. All chemical analyses of wastewater were performed in duplicates in accordance with APHA Standard Methods (1998).

\section{Results and discussion}

Obtained results of OUR tests are shown in figure 3. Experimental points were approximated with linear equation $\mathrm{f}\left(\mathrm{C}_{\mathrm{O} 2}\right)=\mathrm{a} \cdot \mathrm{t}+\mathrm{b}\left(\right.$ where $\mathrm{C}_{\mathrm{O} 2}-$ oxygen concentration in the test reactor, $t$-time), which gave the best fit. For each of the variants, based on average value of coefficient a, volumetric activity of the biomass $\left(v_{o 2}^{V}\right)$ was determined. Values of this parameter are shown in figure 4 . In both series, the highest values of $v_{o 2}^{V}$ were ob- served for hybrid system. Activity of activated sludge was about 0.7 -times lower than the activity observed in variant 3 , but at the same time it was significantly higher than biofilms' activity (I series I: 2.3-times and in series II: 7.7-times higher). The lowest rates of oxygen uptake in relation to active volume of the reactor were obtained for biofilm. They were more than 3-times (series I) and almost 13-times (series II) lower than those in the hybrid system.

Comparing the variants, in which we have single type of biomasses (V1, V2) with the variant in which they are connected (V3), we could expect that the value of the sum of $v_{o 2}^{V}$ for $\mathrm{V} 1$ and V2 will be close to the value of $v_{o 2}^{V}$ for V3. Such dependence was noticed in series I (sum of $v_{o 2}^{V}$ for $\mathrm{V} 1$ and $\mathrm{V} 2$ was $8.98 \mathrm{mg} \mathrm{O}_{2} / \mathrm{L} \cdot \mathrm{h}$ and for $\mathrm{V} 3$ it was $8.94 \mathrm{mg} \mathrm{O}_{2} / \mathrm{L} \cdot \mathrm{h}$ ). However, the results of series II were different. Observed $v_{o 2}^{V}$ for hybrid system was much higher (almost 1.5-times higher than $v_{o 2}^{V}$ of sum V1 + V2). Similar results were obtained by Rosso et al. [2011]. They have examined a full-scale IFAS equipped with AnoxKaldness carriers, which was side-by-side with activated sludge reactors. They have used 
A

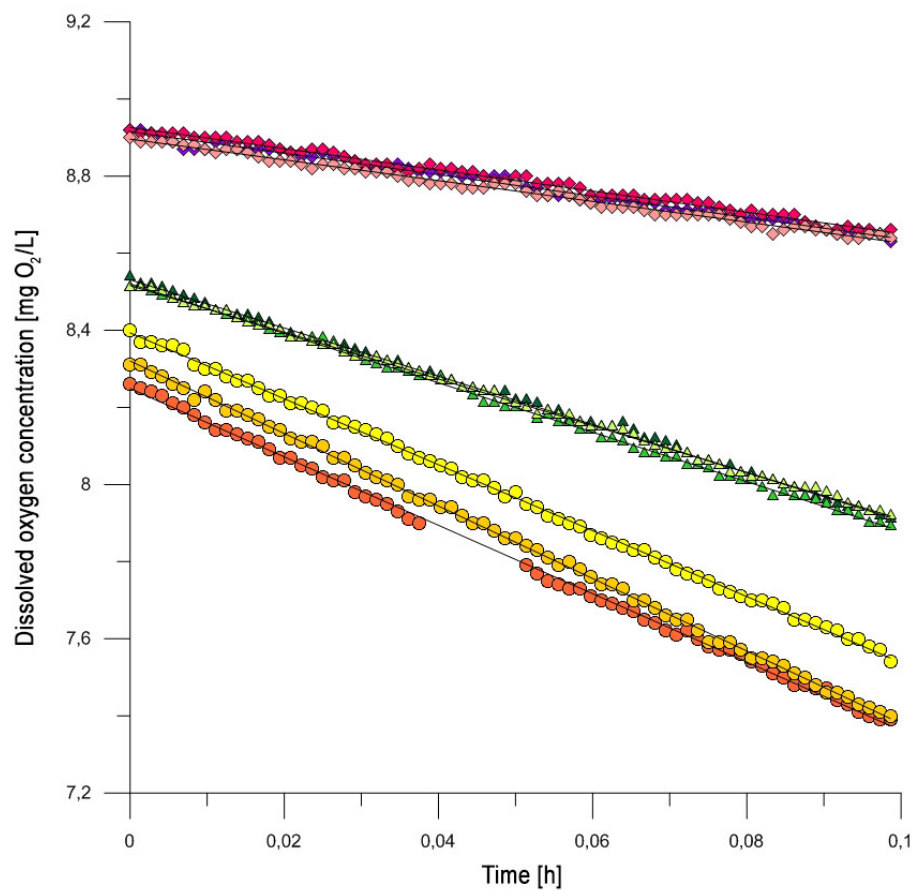

Biofilm - Variant 1

Legend

Repetition $a ; y=-2.78 * x+8.92$

Activated Sludge - Variant 2

Biofilm + Activated sludge - Variant 3

Repetition $b ; y=-2.75^{*} x+8.93$

$\Delta$ Repetition $a ; y=-6.25{ }^{*} x+8.53$

Repetition $a ; y=-8.87^{*} x+8.24$

Repetition $c ; y=-2.96 * x+8.90$

Repetition $b ; y=-6.41 * x+8.52$

Repetition $b ; y=-9.40 * x+8.32$

Repetition $c ; y=-8.55^{*} x+8.39$

B

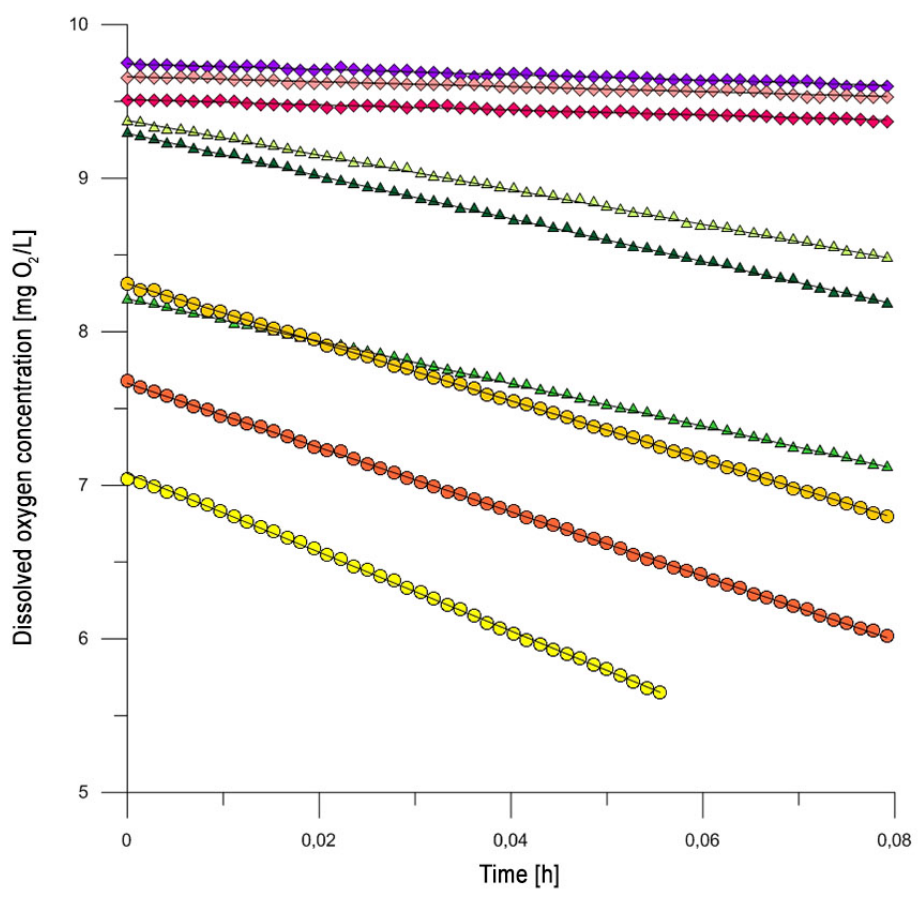

Legend

Biofilm - Variant 1

Repetition $a ; y=-1.76$ * $x+9.74$

Repetition $b ; y=-1.68 * x+9.51$

Repetition $c ; y=-1.62 * x+9.66$
Activated Sludge - Variant 2

$\Delta$ Repetition a; $y=-13.91 * x+9.29$

$\triangle$ Repetition $\mathrm{b} ; \mathrm{y}=-13.82{ }^{*} \mathrm{x}+8.21$

$\triangle$ Repetition $c ; y=-11.28^{*} x+9.38$
Biofilm + Activated sludge - Variant 3

Repetition $a ; y=-20.93^{*} x+7.66$

Repetition $b ; y=-19.07^{*} x+8.31$

Repetition $c ; y=-25.67{ }^{*} x+7.08$

Figure 3. OUR tests results: A) series I, B) series II. 


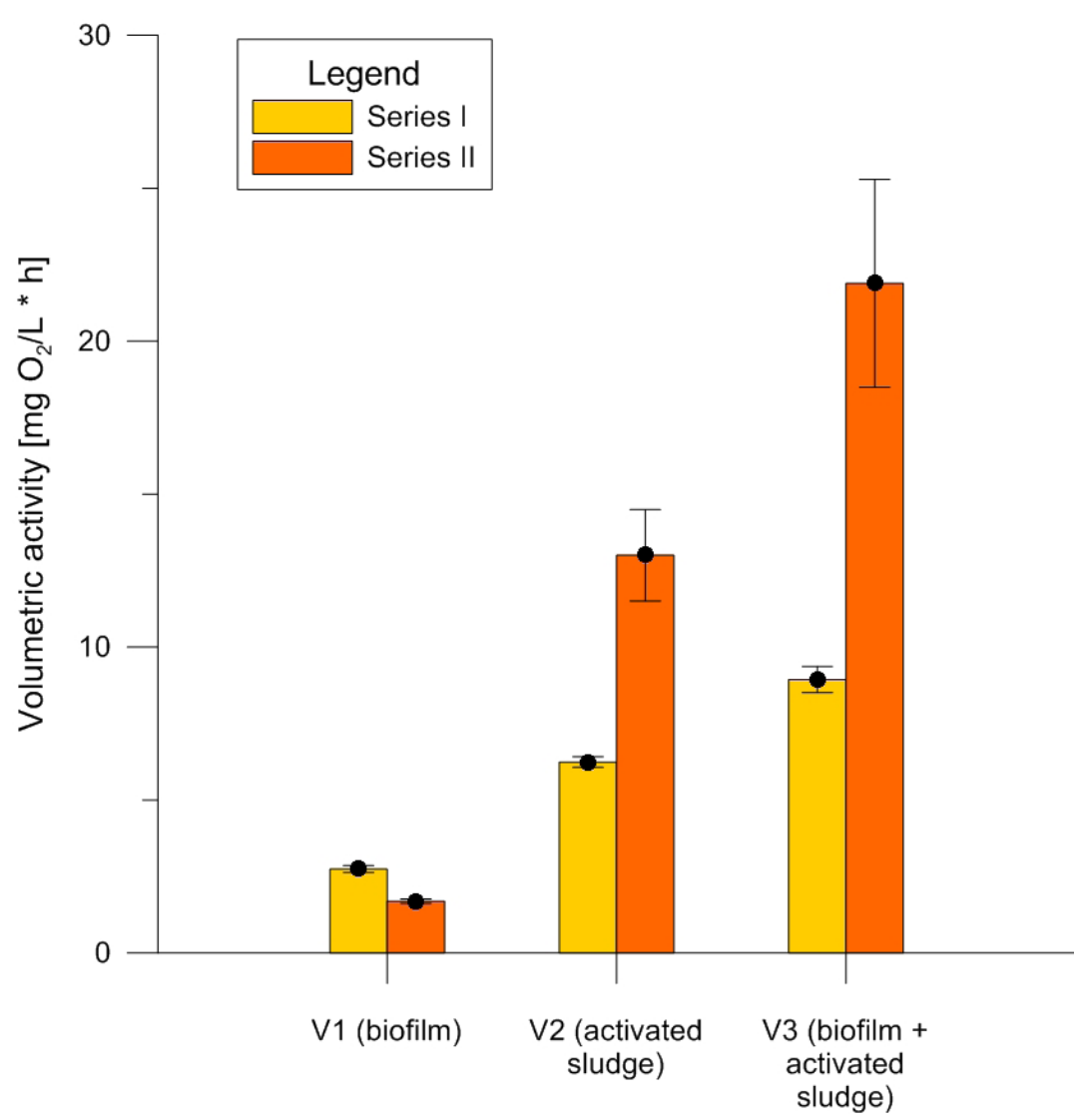

Figure 4. Comparison of volumetric activity of microorganisms developed as biofilm and activated sludge.

off-gas technique and have compared volumetric oxygen uptake rate for activated sludge and for IFAS system. Obtained results have shown, that the activity of biocoenosis of IFAS system was 2.2-times and 2-times higher than for system with activated sludge only.

Based on presented results (Figure 4), it is also possible to assess the role of microorganisms inhabiting two biocoenoses in pollutants removal at the WWTP. Obtained results allow assumption, that during the research period, the main role in organic pollutants removal played microorganisms developed in the form of activated sludge.

When analyzing the obtained results, it is important to take into account the fact, that observed in OUR tests rates of oxygen uptake were not only dependent on the type of used biomass (immobilized, suspended or both), but also on its amount. The data presented in Table 2 show, that significantly lower amount of biomass (expressed in total volatile solids) was present in variant 1 , in which only biofilm was present in the test reactor. Therefore, the factor, which influenced the calculated values of $v_{o 2}^{V}$, was not only the metabolic activity of microorganisms inhabiting studied biocoenoses, but also the amount of the biomass used in the tests. It is worth noticing, that during the experiment, the WWTP was working with relatively high values of mixed liquor suspended solids $\left(6.0-8.0 \mathrm{~kg} / \mathrm{m}^{3}\right)$, which differ remarkably from the value assumed during the design $(4.0 \mathrm{~kg} /$ $\mathrm{m}^{3}$ ) (Table 1), what had an influence on less intense development of biomass in form of biofilm.

In order to take this factor (Table 2) into account, the amount of oxygen used by microorganisms was related to the amount of the biomass in the test reactor. Values of mass activity $v_{o 2}^{m}$ calculated in this way, are shown in Figure 5.

In both series, the biofilm was characterized with much higher values of $v_{o 2}^{m}$ than the activated sludge. Values of $v_{o 2}^{m}$ calculated for V1 were 30and 50-times higher than for V2 in series I and II, respectively. It can be seen that in case of V3, the determined value of $v_{o 2}^{m}$ was 9.6-times higher than for V2, but it was significantly lower than for V1 (5.5-times). It seems possible that in case of V1, the substrates (oxygen and carbon compounds) were constantly available for the whole biomass population and microorganisms could 
Table 2. The amount of biomass used for OUR tests in the test reactor.

\begin{tabular}{|c|c|c|c|}
\hline \multicolumn{3}{|c|}{ Amount of biomass in the test reactor [g TVS] } \\
\hline No. & V1 (biofilm) & V2 (activated sludge) & V3 (biofilm + activated sludge) \\
\hline S1 & 0.0063 & 0.4027 & 0.4090 \\
\hline S2 & 0.0060 & 0.4215 & 0.4275 \\
\hline
\end{tabular}

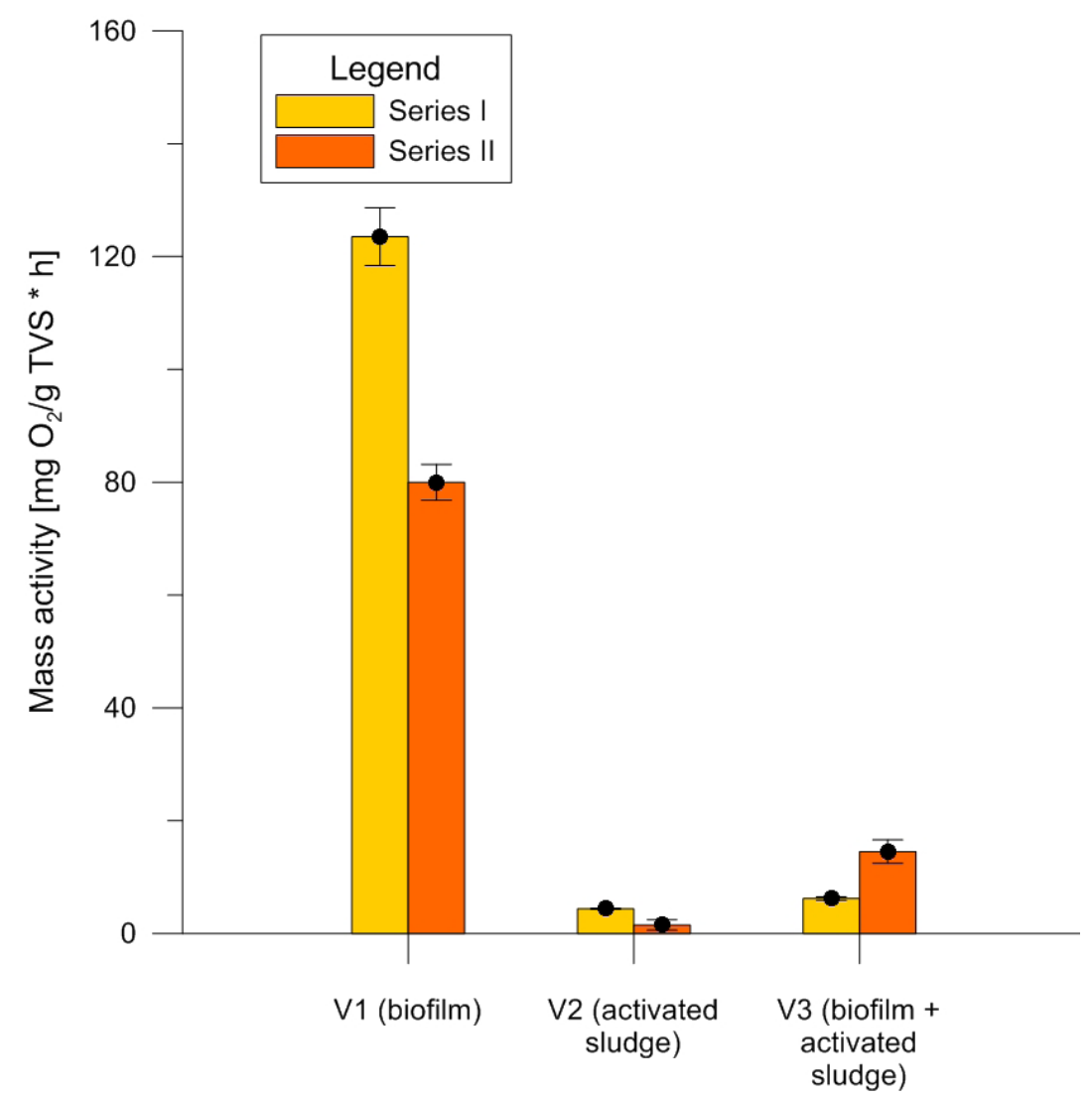

Figure 5. Comparison of mass activity of microorganisms developed as biofilm and activated sludge.

take them up with maximum rate. Probably in case of V2 the amount of biomass was so high, that the substrate diffusion limitation to all bacterial cells occurred. Because the substrate concentration decreased fast, the rate with which they could be taken up by microorganisms also decreased, what had an influence on the mass activity of biomass. In case of volumetric activity $-v_{o 2}^{V}$, it is possible to observe, that for V2 it was higher than for $\mathrm{V} 1$, while for the mass activity $-v_{o 2}^{m}$ we observe opposite situation. Therefore, it is proposed to conduct future OUR tests after assessment of the amount of the biomass attached to the carriers. Such approach will allow for selection of the biomass amount in such way, that it is the same in variants V1 (only biofilm) and V2 (only activated sludge). This approach will allow for unequivocal comparison of metabolic activity of microorganisms inhabiting different biocoenoses.

\section{CONCLUSIONS}

The research covered two series in which OUR tests have been conducted. Obtained results have shown, that the highest volumetric activity was observed for variant with biofilm and activated sludge (8.94 $\mathrm{mg} \mathrm{O}_{2} / 1 \cdot h$ and $21.89 \mathrm{mg} \mathrm{O}_{2} / 1 \cdot h$ in series I and II, respectively), and the lowest for variant with only biofilm $\left(2.74 \mathrm{mg} \mathrm{O}_{2} / \mathrm{L} \cdot \mathrm{h}\right.$ and $1.69 \mathrm{mg} \mathrm{O} / 2 \cdot \mathrm{L} \cdot \mathrm{h}$ in series I and II, respectively). Nonetheless, the highest oxygen uptake rates related to total volatile solids were obtained for variant with biofilm $(123 \mathrm{mg} \mathrm{O} / \mathrm{g}$ TVS. $\cdot \mathrm{h}$ and $80.0 \mathrm{mg} \mathrm{O} / \mathrm{g}$ TVS. ' $\mathrm{h}$ in series I and II, respectively) and the lowest for activated sludge (4.4 $\mathrm{mg} \mathrm{O}_{2} / \mathrm{g}$ TVS $\cdot \mathrm{h}$ and $1.52 \mathrm{mg} \mathrm{O}_{2} / \mathrm{g}$ TVS $\cdot \mathrm{h}$ in series I and II, respectively).

The results of the experiments were influenced by: metabolic activity of microorganisms 
and the amount of biomass in the test reactor. It is probable, that the main role in organic pollutants removal from examined wastewater treatment plant played biomass in form of activated sludge.

Oxygen uptake rate test (OUR) can be proposed as a simple tool for comparison of respiratory activity of biomass developed as biofilm and activated sludge in hybrid reactor with moving bed (IFAS-MBBR).

It was proposed to extend the scope of the experiment to additional OUR tests with an assumption, that the amount of the biomass in reactors: only with biofilm and only with activated sludge will be the same.

\section{Acknowledgements}

This research was supported by the Faculty of Building Services, Hydro and Environmental Engineering, Warsaw University of Technology (grant No. 504/*02642*/1110/42.000100).

\section{REFERENCES}

1. APHA 1998. Standard Methods for the Examination of Water and Wastewater, twentieth ed. American Public Health Association, American Water Works Association, Water Environment Federation Washington, DC, USA.

2. Huang, C., Shi, Y., El-din, M. G., \& Liu, Y. 2016. Performance of flocs and biofilms in integrated fixed-film activated sludge ( IFAS ) systems for the treatment of oil sands process-affected water (OSPW). Chemical Engineering Journal. http:// doi.org/10.1016/j.cej.2016.11.151

3. Jabari, P., Munz, G., \& Oleszkiewicz, J.A. 2014. Selection of denitrifying phosphorous accumulating organisms in IFAS systems: comparison of nitrite with nitrate as an electron acceptor. Chemosphere, 109, 20-27. http://doi.org/10.1016/j.chemosphere.2014.03.002

4. Kim, H.-S., Schuler, A.J., Gunsch, C.K., Pei, R., Gellner, J., Boltz, J.P., et al. 2011. Comparison of conventional and integrated fixed-film activated sludge systems: attached- and suspended-growth functions and quantitative polymerase chain reaction measurements. Water Environment Research : A Research Publication of the Water En- vironment Federation, 83(7), 627-635. http://doi. org/10.2175/106143010X

5. Leyva-Díaz, J.C., González-Martínez, A., González-López, J., Muñío, M.M., \& Poyatos, J.M. 2015. Kinetic modeling and microbiological study of two-step nitrification in a membrane bioreactor and hybrid moving bed biofilm reactormembrane bioreactor for wastewater treatment. Chemical Engineering Journal, 259, 692-702. http://doi.org/10.1016/j.cej.2014.07.136

6. Maider, S., Gabaldon, C., Zalakain, G., \& Larrea, L. 2015. Optimum design and operation of SBRIFAS process for maximum nutrient removal in small WWTPs, 520-527.

7. Onnis-Hayden, A., Majed, N., Schramm, A., \& $\mathrm{Gu}$, A.Z. 2011. Process optimization by decoupled control of key microbial populations: Distribution of activity and abundance of polyphosphateaccumulating organisms and nitrifying populations in a full-scale IFAS-EBPR plant. Water Research, 45(13), 3845-3854. http://doi.org/10.1016/j.watres.2011.04.039

8. Podedworna J. , Żubrowska-Sudoł M. 2011. Why use waste-based bioreactors in waste water technology? Gas, Water and Sanitary Engineering, 9, 324-327 [in Polish].

9. Rosso, D., Lothman, S. E., Jeung, M. K., Pitt, P., Gellner, W. J., Stone, A. L., \& Howard, D. 2011. Oxygen transfer and uptake, nutrient removal, and energy footprint of parallel full-scale IFAS and activated sludge processes. Water Research, 45(18), 59875996. http://doi.org/10.1016/j.watres.2011.08.060

10. Surmacz-Gorska, J., Gernaey, K., Demuynck, C., Vanrolleghem, P., \& Verstraete, W. 1996. Nitrification monitoring in activated sludge by oxygen uptake rate (OUR) measurements. Water Research, 30(5), 1228-1236.

11. Zhang, P., Guo, J.-S., Shen, Y., Yan, P., Chen, Y.P., Wang, H., et al. 2015. Microbial communities, extracellular proteomics and polysaccharides: A comparative investigation on biofilm and suspended sludge. Bioresource Technology, 190, 21-28. http://doi.org/10.1016/j.biortech.2015.04.058

12. Żubrowska-Sudoł M. 2012. Moving bed technology as an alternative solution for reducing bioreactor volume, Environment Protection Engineering, Vol. 38, No 3, 15-22.

13. Żubrowska-Sudoł M., Jasińska A. 2007. Division of reactors with mobile bed. Gas, Water and Sanitary Technology, 3, 29-31 [in Polish]. 